\title{
Glacial Ridge National Wildlife Refuge: A Partnership from the Beginning
}

\author{
By Mark Hayek
}

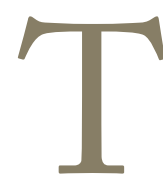

he first time I visited the recently established Glacial Ridge National Wildlife Refuge (GRNWR), it became apparent to me that this was no ordinary conservation project. Upon glancing across the acres of restored tallgrass prairie and wetland basins, one begins to realize that a single organization could not have tackled this project alone. It is astounding to think over 30 partnering organizations were involved in the Glacial Ridge Project. Getting just two organizations pulling in one direction can be difficult at times and working with partners isn't always easy, or successful, but the Glacial Ridge Project can provide all of us with insight on how to make partnerships work.

The Glacial Ridge Project had many challenges and complexities that required an armada of organizations pulling in the right direction. I invite you to read further; I hope to share with you the brief history behind the land, explain the obstacles the partnerships overcame, reveal the birth of a National Wildlife Refuge, and provide an example of how partnerships are still playing an important role in the management of GRNWR. Perhaps I can offer examples of why these partnerships were successful, or more importantly how these partnerships overcame challenges to make this project a reality.

\section{Location and Landscape of GRNWR}

GRNWR is located in northwestern Minnesota, seven miles east of Crookston, Minnesota (Fig. 1), and lies within the northern tallgrass prairie region. The northern tallgrass prairie once extended from central Iowa through eastern South and North Dakota, western Minnesota, and as far north as southern Manitoba. ${ }^{1}$ The landscape within the GRNWR and surrounding area consists of multiple beach ridges and interbeach formations produced by ancient Glacial Lake Agassiz (Fig. 2). Groundwater seep areas are a common feature within this glacially formed landscape. GRNWR lies between two prominent beach ridge formations, and is a part of the eastern shoreline of the ancient lake. Periods of stable lake levels formed the two prominent strand lines (beach ridges): the Campbell and the Herman. Small strandlines formed in between the Campbell and
Herman as the lake's water table experienced cycles of retreat and stabilization. These strandlines give the GRWNR its unique landscape and also its name.

Present-day land use surrounding the refuge includes idled grasslands and cropland. The vegetation within GRNWR can be summarized as dry prairie dominating the sand and gravel ridge tops, with wet prairie, sedge meadows, and deep marshes occupying the interbeach areas. In Minnesota and Iowa, 10 million ha of northern tallgrass prairie is thought to have existed; less than 134,000 ha of this native grassland

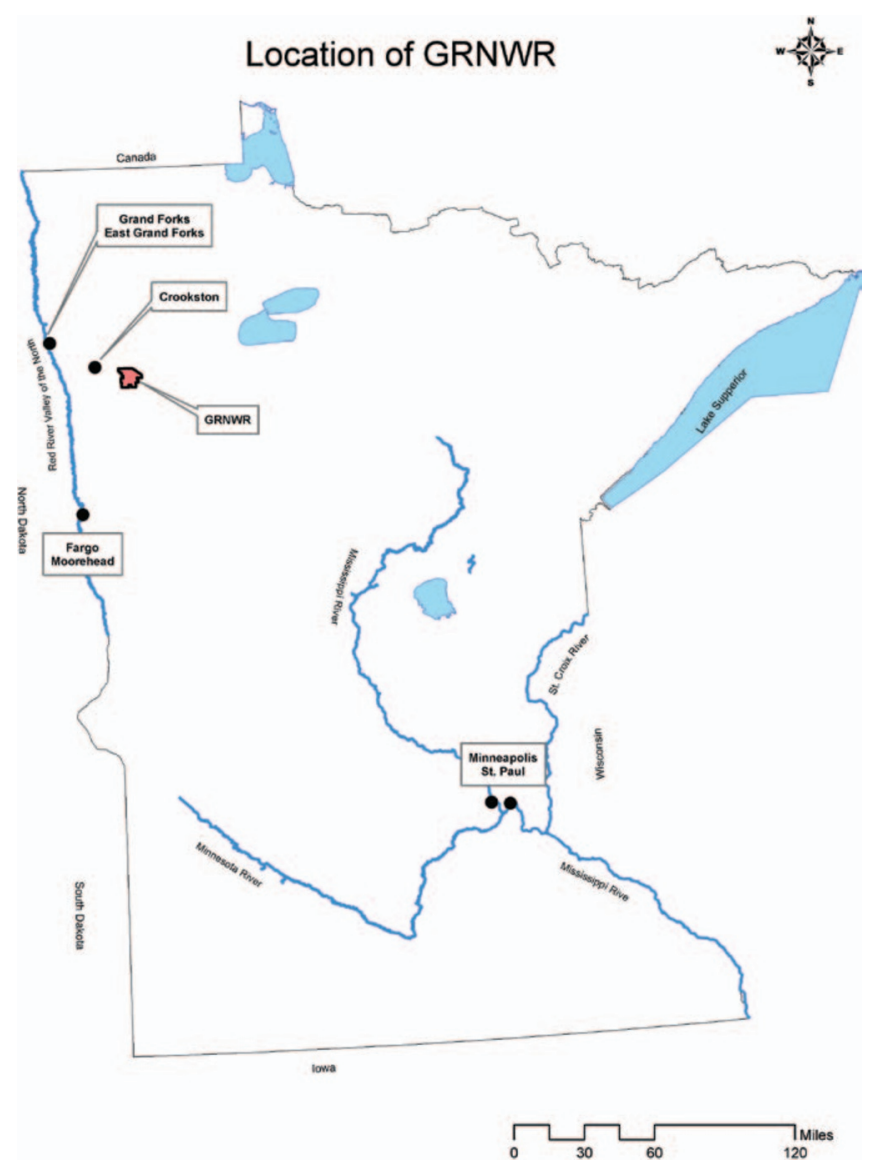

Figure 1. General location of Glacial Ridge National Wildlife Refuge (GRNWR) within Minnesota. 


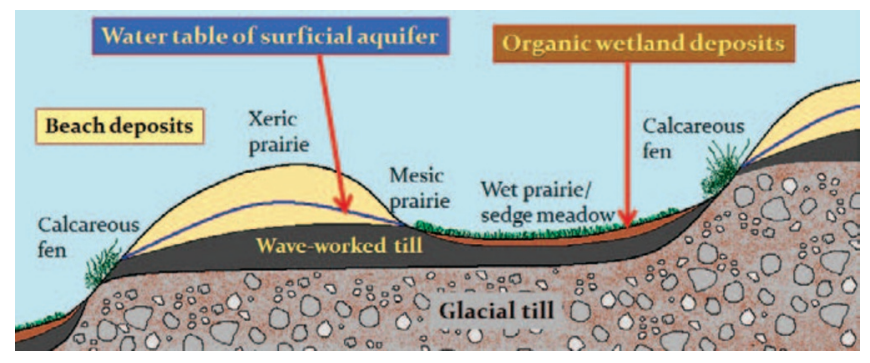

Figure 2. Generalized profile of beach ridges showing materials, hydrology, and plant communities. The vertical landscape has been exaggerated for illustration. ${ }^{6}$

community remains. ${ }^{2}$ The opportunity to conserve a combination of rare landscape features and restore a dwindling northern tallgrass prairie does not happen on a regular basis.

\section{History}

Prior to 2000, GRNWR was owned by various individuals or corporations. In the early 1950s the property was consolidated, and by 1964, the plat records reveal the land being owned by Minn-Tex Meadow Ranch., By 1970, the MinnTex Meadow Ranch was sold to Crookston Cattle Company, who owned and operated the property until the early 1990s when it was sold and became known as Tilden Farms (named after its township).

In the early 1970s, within Tilden Farms and the surrounding area, agriculture began to shift from livestock to crop farming. During the 1990s Tilden Farms was mostly drained, plowed, and cropped. Small portions of native upland grasslands remained because livestock were still being raised on the property. In 1998, a small group of investors from Missouri purchased Tilden Farms and one of the investors approached the local United States Department of

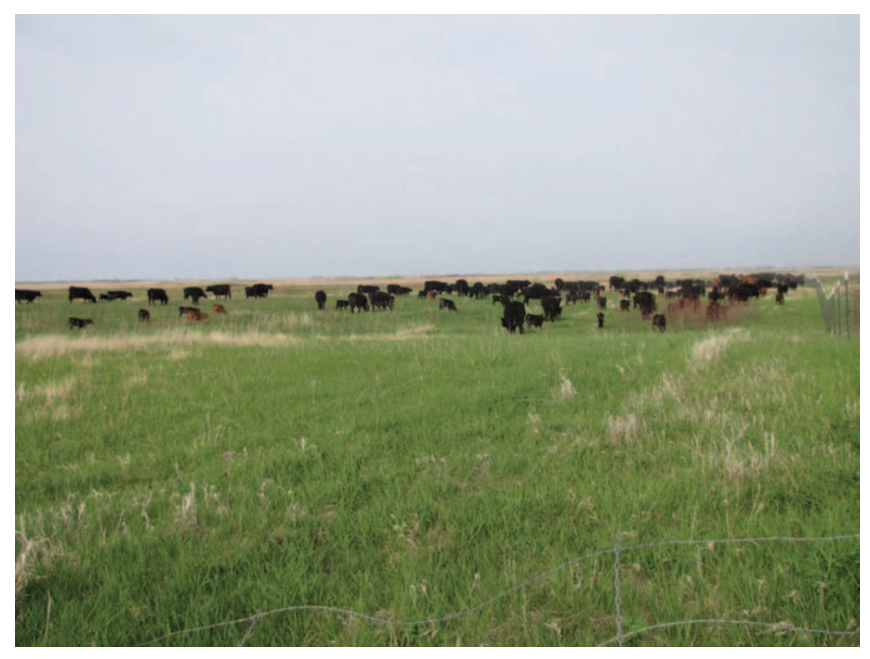

Cattle grazing a patch-burn unit within Glacial Ridge National Wildlife Refuge (GRNWR), 2010. Grazing is often an underutilized tool to help manage northern tallgrass prairie restorations. Photo by Mark Hayek. Photo courtesy of the USDA Natural Resources Conservation Service.
Agriculture (USDA) office about enrolling the farm into the USDA farm programs.

Until 1998 the property of Tilden Farms had never been enrolled in the USDA farm programs, which presented problems under the Wetland Conservation (SwampBuster) provisions of the Food Security Act of 1985. SwampBuster prohibits USDA participants from draining and cropping wetlands after December 23, 1985. Because Tilden Farms did not participate in the USDA programs, they did not fall under the SwampBuster jurisdiction of the Food Security Act of 1985. It was these cropped areas that provided a sticking point in the process to enroll in USDA farm programs; in order to be eligible for USDA farm programs, Tilden Farms would need to restore these converted (after 1985) wetlands.

The USDA Farm Bill Wetland Reserve Program (WRP) was the perfect fit to restore the drained wetlands (and associated cropped upland acres) and to conserve the Tilden Farms' fragile soils. The USDA Natural Resources Conservation Service (NRCS) defines the WRP program as, “... a voluntary program offering landowners the opportunities to protect, restore, and enhance wetlands on their property. NRCS provides technical and financial support to help landowners with their wetland restoration efforts. The NRCS goal is to achieve the greatest wetland functions and values, along with optimum wildlife habitat, on every acre enrolled in the program. This program offers landowners an opportunity to establish long-term conservation and wildlife practices and protection. ${ }^{5} \mathrm{WRP}$ is a permanent easement program, and it was around this time The Nature Conservancy (TNC) began to negotiate a complete purchase of Tilden Farms from the Missouri group. Part of the sale included the Missouri group selling enrolled WRP acres to TNC. A core partnership was formed with TNC, NRCS, and ultimately the United States Fish and Wildlife Service (USFWS). USFWS agreed to adopt the entire acreage as a National Wildlife Refuge upon completion of the WRP restorations. This entire project required convincing a skeptical public.

\section{Partnerships, Taxation, Water, and Gravel}

Prior to the initial TNC land purchase in 2000, multiple issues needed to be addressed, and a majority were at the local and regional levels. These barriers included: fear and concern of lost property tax revenue if this land fell in control of the government, skepticism about drainage issues with the planned wetland restorations, and a regional unease about the future source of gravel if mining would not be allowed in the proposed project area. The core partners understood the importance of addressing these barriers, and outside partnerships were formed to strengthen local, state, and national support for the vision of the Glacial Ridge Project (Table 1).

Mounting local concern for the loss of property tax revenue if Tilden Farms fell under governmental or nonprofit ownership caused the core partnership to act. Part of the property tax solution was addressed through the USFWS Refuge Revenue Sharing program (on lands owned by USFWS) as a way that 
payments could be offered in lieu of property taxes). The Refuge Revenue Sharing program offers the local unit of government levying property taxes the higher of: " $3 / 4$ of 1 percent of the fair market value; 25 percent of net receipts; or $\$ 0.75$ per acre." It became apparent that the fear of losing local property taxes was not going to derail the Glacial Ridge Project, or the partnerships striving to make it happen. Most of the concern was dealt with by the Refuge Revenue Sharing program, but these funds did not provide enough revenue to garner the support needed for the project. TNC created an endowment fund to strengthen the Refuge Revenue Sharing program and provide additional revenue in lieu of taxes. Interest drawn from this endowment fund can only be used for payments in lieu of taxes, and this innovative idea between the partnerships gained the support needed to push the project forward.

The property tax issue was just one of a complex set of obstacles that found their way in the path of the project. GRNWR is comprised of 10 different subwatersheds. Most of my range colleagues can identify with lack of water, but in NW Minnesota, too much water and not enough drainage can cause a ruckus at a moment's notice; drainage issues in this part of the world can stop any project in its tracks. The core partnership had to find a way to quell the concerns of neighbors and downstream landowners that they would not be affected by the wetland restorations being planned within GRNWR. TNC called upon the United States Geological Survey (USGS) and the University of North Dakota (UND) to study, monitor, and record hydrology data within, adjacent to, and downstream of the Glacial Ridge Project. Soon the Red Lake Watershed District was assisting USGS and UND in setting up a long-term monitoring study of the area. Although there are monitoring devices and studies in place, there are still some local concerns about the drainage and water levels in the area. By inviting stakeholders (adjacent landowners) and supporting organizations specializing in hydrology to the table, the partnership showed it cared about this important concern, and brought third parties to the table to monitor the effects and impacts of the wetland restorations.

Gravel is an important natural resource region wide, and many local communities benefit from the taxes levied from the mining of this valuable resource. If the gravel operations were to be closed, alternative gravel would need to be trucked into this area at a higher cost with less convenience. Prior to the purchase of Tilden Farms, a single aggregate company held mineral rights to all 9,000 ha of Tilden Farms. The fear of losing convenient access to the inexpensive gravel within the project area and the tax revenue it generates was enough concern to cause local political and business leaders to take a second look at the project. Negotiations began between TNC, USFWS, and the aggregate mining company to determine how gravel mining would proceed. Shortly after the initial purchase, the outcome of the negotiations yielded a compromise which allowed gravel mining on five lease areas covering $6.5 \%$ of the original Tilden Farms tract. In addition to negotiating with
Table 1. Major contributing partners in the Glacial Ridge National Wildlife Refuge project*

The Nature Conservancy

USDA Natural Resources Conservation Service

US Fish and Wildlife Service

Ducks Unlimited

US Geological Survey

Environmental Protection Agency

Minnesota Department of Natural Resources

Minnesota Pollution Control Agency

Minnesota Department of Commerce

North Dakota State University

University of Minnesota, Crookston

University of North Dakota

South Dakota State University

Concordia College

Polk County

City of Crookston

Red River Basin Board

Red River Flood Damage Work Group

Minnesota Waterfowl Association

Bush Foundation

Nature Northwest

Multiple area watershed districts, county and township boards, and neighboring land owners and citizens

*For a complete list, see the Minnesota Nature Conservancy Glacial Ridge project Web site, http://www.nature. org/ourinitiatives/regions/northamerica/unitedstates/ minnesota/placesweprotect/glacial-ridge-project.xml. 


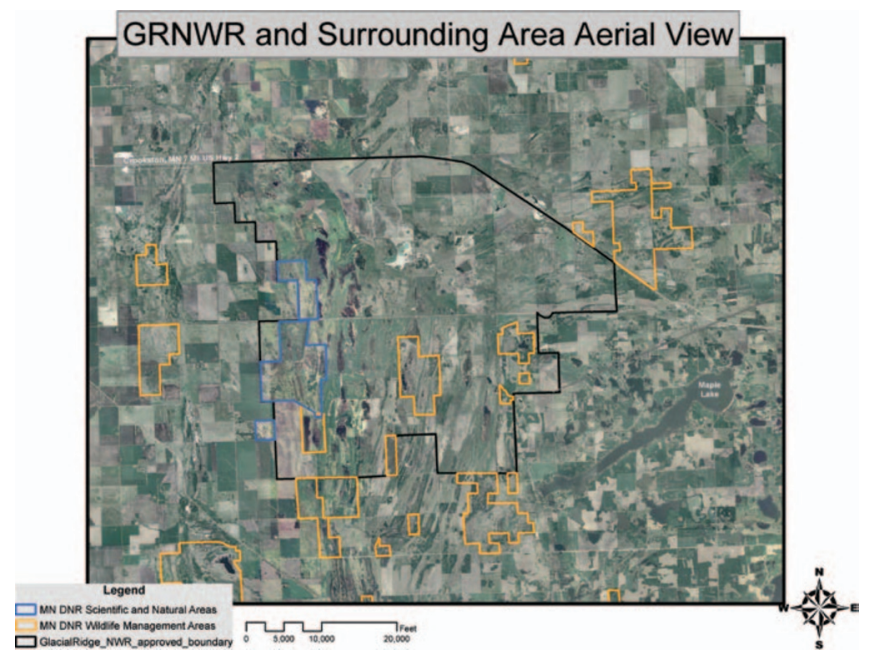

Figure 3. Aerial photo of Glacial Ridge National Wildlife Refuge (GRNWR) and surrounding area.

the gravel operator, the core partners pulled in Polk County Department of Transportation and local township officials to address the long-term supply of gravel coming out of the Refuge. This again demonstrates that the partnerships are willing to compromise, be flexible, and incorporate other groups into the decision making process.

There was no shortage of challenges the core partnership faced, and with the initial land purchase on the horizon, the real task was just beginning. The core partners had a new challenge: to complete the largest tallgrass prairie restoration project the world has seen. ${ }^{6}$

\section{Birth of a Refuge}

The hard work and determination by the core partnership eventually led to the initial purchase of 9,822 ha in August of 2000 by TNC. The core partnership began working to restore the prairie and wetlands mainly through the WRP easement monies set aside for the restoration phase of the WRP easement contracts. Neighboring landowners also enrolled into the WRP (nearly 1,620 ha) which provided additional conservation easements to the project. Since restoration began in 2001 , over 8,100 ha have been enrolled into the WRP program, yielding close to 250 wetland basins being restored and over 6,070 ha of upland prairie being seeded to local ecotype varieties consisting of a 15 -species grass and forb mixture. However most of the seed was harvested on nearby prairies that exceeded the WRP seeding recommendations.

On October 12, 2004, GRNWR was established and authorized at a size of 15,280 ha, and became our nation's 545th National Wildlife Refuge (Fig. 3). New partnerships were formed with various local and regional researchers to provide research on and monitoring of vegetation, amphibian, and avian populations to gauge the impact and effects of the wetland and grassland restorations. Photo points have been established throughout the GRNWR to provided additional data to monitor these restorations. Today, the restora- tions within the refuge are nearly completed and nearly all of the acres have been transferred to the USFWS. Although the progress of the restoration phase is nearing an end, the work of managing the GRNWR is just beginning.

\section{Short- and Long-Term Management Collaboration}

The northern tallgrass prairie evolved with three main disturbance factors: frequent fires, grazing, and drought. The disturbance-driven ecosystem of the northern tallgrass prairie provides challenges to managers wishing to mimic these events. The next big test facing GRNWR is how to manage these restored wetlands and grasslands now and in the future. The major threats to undermine the restorations include: noxious and invasive weed encroachment across all vegetative communities, cattail population expansion into wetland basins, and maintaining plant and wildlife diversity. The partnerships did not end with the purchase and restoration of GRNWR, and partnerships are still an important element to the management of this landscape. An example of how the core partnership continues to collaborate is a project demonstrating patch burn grazing $(\mathrm{PBG})$ as a management technique for restored northern tallgrass prairie.

In 2008 USFWS, TNC, and NRCS began to discuss PBG management plan within the South Oxcart (SO) unit. The $\mathrm{SO}$ unit is an 813-ha parcel that has been restored in various stages between 2005 and 2007, with 613 ha of upland prairie and 200 ha of wetland basins. The management objectives of PBG include: treating the spread of invasive species (i.e., reed canary grass), improve vertical plant diversity within the landscape of GRNWR, diversify grassland bird habitat within GRNWR and the surrounding area, encourage forb production, and provide disturbance mechanisms with which this landscape historically evolved.

In the summer of 2010, the perimeter fence was constructed around the PBG unit and a permittee was selected in the fall of 2010. A grazing permit was issued to a local livestock producer for the period of four years (2011-2015). Upon expiration of the permit, the core partnership will decide if the PBG management plan was successful in meeting the management objectives of the unit. If successful, it is anticipated more GRNWR acres will be treated with the PBG management plan.

USFWS instituted a vegetative, avian, and small mammal monitoring program to help gauge trends and results from the PBG management plan. The core partnership has also solicited local and regional researchers from North Dakota State University and the University of Minnesota Crookston to help gather data for monitoring. The PBG management project at GRNWR will serve to provide great insight into the uses and limitations of prescribed fire and grazing as it relates to the management of restored northern tallgrass prairie.

\section{Conclusion}

A dozen years have passed since the initial land purchase of the Glacial Ridge Project. By researching the partnerships 


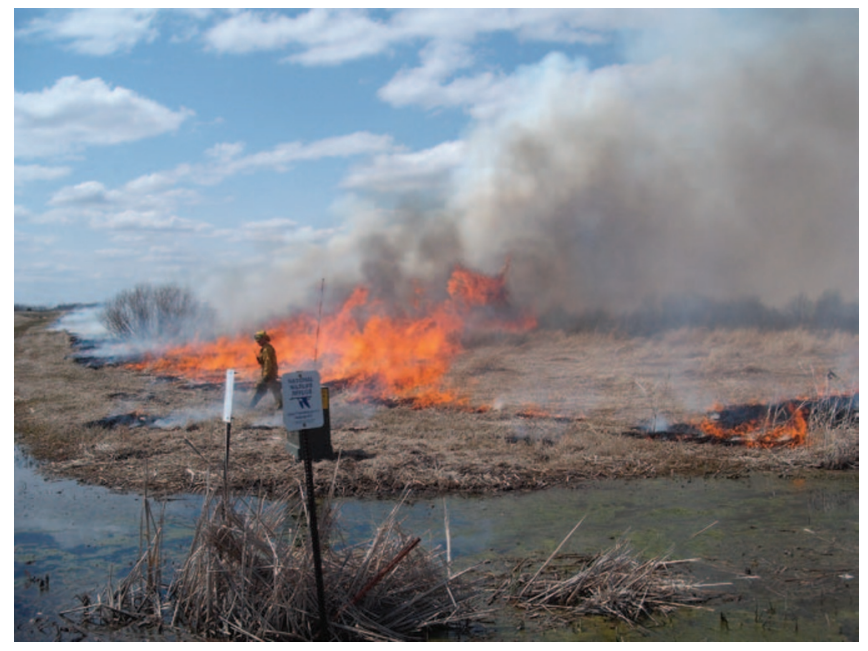

A prescribed fire within Glacial Ridge National Wildlife Refuge (GRNWR). 2009. Prescribed fire is an often used tool to help manage northern tallgrass prairie. Photo courtesy of the USDI-Fish and Wildlife Service.

that went into making this project a reality it is hard for me to imagine what the outcome would have been without the successful partnering that went into this complex mission. The core partnership involved with the Glacial Ridge Project has left lasting lessons for all of us to learn, but the most important lesson is that successful partnerships can accomplish great things. The visits to GRNWR remind me not only what a beautiful place it is, but how attractive partnerships can be. I would like to leave you with some important traits that made partnerships successful in establishing the GRNWR:

- Values. Values and goals must be shared across the partnership. In this project conservation was highly valued by the core partnership, and it motivated the partnership to move past the major obstacles.

- Quality. The quality of the partnership is greater than the quantity. Navigating the major obstacles required innovative and diverse thinking. TNC and USFWS displayed how strong their partnership was by working together to provide an innovative in-lieu-of tax arrangement, with TNC creating the endowment fund to supplement the Refuge Revenue Sharing program.

- Honesty. Identify those groups that can strengthen your position, and they just might be able to push your project past the finish line. Knowing your weaknesses helps to identify those organizations that can strengthen the project. This takes being honest with yourself and your organization. How the partnership addressed the drainage and flooding issues by bringing third parties to the table was a shrewd and valuable move to provide more specialized, accurate, and credible resources to monitor this important issue.

- Flexibility. The larger the project, the more willing you need to be to expand your partnership. Organizations from private, local, state, regional, or national levels can help to cover all of the bases. Being flexible enough to include new partners shows a determination to get the project completed. Flexibility can also mean compromising lesser values for the better of the mission or partnership. The willingness to compromise proved the partnership could work with opposing groups, but also provide leadership which became invaluable in solving how the project was going to handle the gravel-mining issues.

- Trust. Strong partnerships can transcend projects, and metamorphose into other opportunities. In Minnesota, the Glacial Ridge Project has brought agencies closer together and more willing to work as partners. Trusting in your partner is, arguably, the most important quality.

\section{References}

1. McNab, W. H. 1994. Ecological subregions of the United States. USDA Forest Service. Available at: http://www.fs.fed. us/land/pubs/ecoregions/ch28.html. Accessed 18 December 2010.

2. USDi-Fish and Wildlife Service. 2011. Northern Tallgrass Prairie NWR. US Fish and Wildife Service Midwest Region Division of Conservation Planning. Available at: http://www.fws. gov/midwest/windom/ntg_prairie_nwr.html. Accessed 12 December 2011.

3. Atlas of Polk County, Minnesota. 1954. Fergus Falls, MN, USA: Thomas O. Nelson Company. 147 p.

4. Atlas of Polk County, Minnesota. 1964. Fergus Falls, MN, USA: Thomas O. Nelson Company. 152 p.

5. USDA-NRCS. 2010. Wetland Reserve Program. Available at: http://www.nrcs.usda.gov/wps/portal/nrcs/main/national/programs/easements/wetlands Accessed 6 December 2011.

6. Johnson, Rhett. 2006. The beach ridges of the Glacial Ridge area. St. Paul, MN, USA: University of Minnesota, Crookston, and USDA-NRCS Minnesota. 4 p.

Author is NW Regional Grazing Specialist, USDA-NRCS, Thief River Falls, MN 56701, USA, mark.hayek@mn.uda.gov. 